\title{
EU states back biotech patent reforms
}

London. The governments of the 12 member states of the European Union (EU) last week approved a European Commission directive that would standardize their national laws on patenting life. But five years of negotiations may yet come to nothing if, as seems probable, the European Parliament vetoes the entire proposal.

The commission had revised a pro-industry draft, initially produced in 1988 , following fierce opposition from the European Parliament. Members of the parliament want stringent conditions on patenting innovations in human, animal and plant genetics, reflecting widespread concern about the social and ethical implications of such techniques.

As a result, the revised directive, approved by EU trade ministers at a meeting in Brussels, acknowledges the concerns of animal welfare groups by forbidding patents on processes for creating transgenic animals and on the animals themselves - - where the suffering or physical handicaps on the animals concerned are "out of proportion to the objective pursued".

The directive also rules that parts of the human body "as such" (including cells proteins, genes, and - at the insistence of Italy - "the products of conception") should not be patented. It accepts, however, that "isolated parts", including complete genes of known utility, should not be unpatentable simply because of their human origin.

Another major concession would let farmers sow seeds from their own crops on their own fields without paying further royalties. The so-called farmer's privilege has provoked strong feelings, especially in developing countries. Both the Uruguay Round of the General Agreement on Tariffs and Trade and the revised UPOV convention on the protection of plant varieties have left the question open for individual countries to settle as they see fit.

The biotechnology industry unanimously supported the original directive. But it is now divided in its opinion. One school of thought says that no directive is better than the revised directive. For example, a representative of the UK Bioindustry Association says that while the farmer's privilege is appropriate to traditionally bred varieties, it will prevent companies producing transgenic crops from recovering the costs of research and development.

Opponents also say that the directive's original objective of clarifying patent legislation in Europe is not as important as it was five years ago, because subsequent decisions by the European Patent Office (EPO) have shown that the European Patent Convention does not prohibit patents on plants and animals. They are concerned that now the directive will complicate patent decisions by formalizing ethics as a criteria for patenting, beyond novelty, non-obviousness and usefulness.

But Nigel Pool, head of external regulatory affairs at Zeneca Seeds, says that the details of the directive are secondary to its political importance, and that if it is passed, it will send a strong message of confidence to investors in European biotechnology.

The EU ministers' approval is said to be linked to the publication the week previously of Jacques Delors' white paper (policy document) on competitiveness, growth and unemployment, which identifies biotechnology as one of Europe's three key growth areas.

But animal rights groups and medical charities feel that the directive does not go far enough in restricting patents on either animals or human genes; and the stage is now set for a fierce debate when the revised proposals - once confirmed by the

full Council of Ministers — are returned to the European Parliarinent for a second reading.

Here feelings run high. Earlier this year, for example, the parliament overwhelmingly passed a resolution calling on the EPO to reverse its decision to issue a patent on Harvard University and Dupont's "Oncomouse".

Under the Maastricht treaty, final approval of new national legislation will require a single text thrashed out by a conciliation committee, and accepted by majorites in both the Council of Ministers and parliament.

Many observers believe that the strong emotions provoked by animal and gene patents are making the chances of reaching agreement on socially-acceptable patent legislation increasingly remote.

David Dickson and Declan Butler

\section{Reprocessing plant gets green light}

London. Almost two-thirds of those who replied to the British government's request for comments about Thorp the thermal oxide reprocessing plant built by British Nuclear Fuels (BNFL) at Sellafield - said that they were opposed the plant's operation.

The most popular arguments against starting up the plant were concern about the increase in radioactive discharges into the environment (quoted by 29 per cent of respondents), and demands that no decision should be taken before a new public enquiry ( 29 per cent), a point raised last week in a letter from almost 30 members of the US Congress to Prime Minister John Major.

Despite such objections, BNFL was given permission to start operation last week, signalling the government's decision to leave the question of whether to reprocess or not up to market forces, as long as the appropriate environmental and non-proliferation criteria are satisfied.

The strongest arguments quoted by respondents in favour of allowing the plant to start up were its commercial benefits, quoted by 35 per cent - BNFL estimates that the reprocessing plant will generate about $£ 2$ billion for the British economy - and general comments in favour of reprocessing.

Over 42,500 responses were received during the two month consultation period. Letters were received from Japan, Australia and Ireland as well as the UK, of which a total of 63 per cent were opposed to the operation of the reprocessing plant.
Fiona Gammie
Support for arguments against and in favour of Thorp

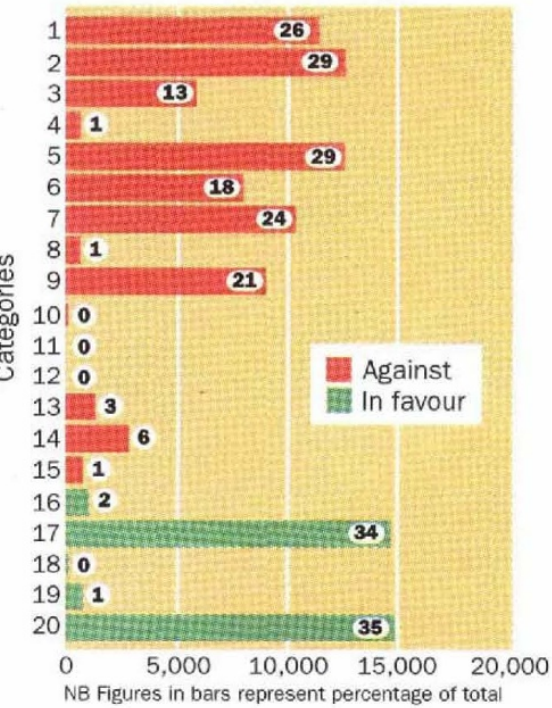

Code: Arguments against Thorp: 1 no justification for reprocessing; 2 calls for public hearing/public inquiry; 3 second consultation; 4 increase in $\mathrm{Kr}-85$ and $\mathrm{I}-129$ discharges; 5 increase in discharges; 6 increase in stockpiles of plutonium; 7 human health effects; 8 assessment methods ; 9 discharges from Sellafield adversely affect environment; 10 waste management; 11 current litigation; 12 authorizations/ assessments don't comply with legislation; 13 risk/accident during transport of radioactive waste; 14 risk of accident at Sellafield; 15 environmental image of Britain.

Arguments in favour: 16 trading image of Great Britain: 17 pro reprocessing; 18 new authorization; 19 no inquiry; 20 economic benefit. 